\title{
Identifying the most effective tool to assess health status of patients with acute exacerbation of chronic obstructive pulmonary disease -a prospective study
}

ping chen ( $\nabla$ pingchen00731@126.com )

respiratory disease institute of hunan province

Aiyuan Zhou

the second xiangya hospital

Zijing Zhou

the second xiangya hospital

Dingding Deng

the first affiliate hospital of shaoyang college

Yiyang Zhao

the second xiangya hospital

Jiaxi Duan

the second xiangya hospital

Research article

Keywords: COPD, acute exacerbation, FENO, CAT, curative effect

Posted Date: January 15th, 2020

DOI: https://doi.org/10.21203/rs.2.14468/v2

License: (c) (i) This work is licensed under a Creative Commons Attribution 4.0 International License.

Read Full License 
The authors have withdrawn this preprint from Research Square 